\title{
Assessing the Impact of Financial Inclusion on Inflation Rate in Developing Countries
}

\author{
Mehry El Bourainy ${ }^{*}$, Ashraf Salah², Marwa El Sherif ${ }^{1}$ \\ ${ }^{1}$ Finance Department, College of Management and Technology, Arab Academy for Science and Technology, Giza, Egypt \\ ${ }^{2}$ Finance Department, College of Management and Technology, Arab Academy for Science and Technology, Alexandria, Egypt \\ Email: *mehryelbourainy@aast.edu
}

How to cite this paper: El Bourainy, M., Salah, A., \& El Sherif, M. (2021). Assessing the Impact of Financial Inclusion on Inflation Rate in Developing Countries. Open Journal of Social Sciences, 9, 397-424. https://doi.org/10.4236/jss.2021.91030

Received: December 11, 2020

Accepted: January 25, 2021

Published: January 28, 2021

Copyright (c) 2021 by author(s) and Scientific Research Publishing Inc. This work is licensed under the Creative Commons Attribution International License (CC BY 4.0).

http://creativecommons.org/licenses/by/4.0/ (c) (i) Open Access

\begin{abstract}
Interest in promoting financial inclusion has increased dramatically in recent years all over the world. The aim of this study is to empirically assess the impact of financial inclusion on the inflation rate in 37 developing countries for a period of 10 years from 2009 to 2018. Initially, Principal Component Analysis (PCA) has been utilized to construct a new multidimensional Financial Inclusion Index (FII) using three dimensions; access, usage, and quality of financial services. Next, 2 step system, Generalized Method of Moments (GMM) was applied to assess the impact of financial inclusion on the inflation rate empirically. The study established that an increased level of financial inclusion has an impact on decreasing the inflation rate in developing countries. It was also found that interest $r$ and official reserves have a significant positive impact on inflation rate. These findings recommend that the policymakers in developing countries should consider financial inclusion as a tool for decreasing the inflation rate and accordingly boost the level of financial inclusion in their countries. Broadening financial inclusion to the informal sector and the rural areas could help in promoting the status of financial inclusion in developing countries.
\end{abstract}

\section{Keywords}

Financial Inclusion, Developing Countries, Inflation Rate, PCA, System GMM

\section{Introduction}

Alliance for Financial Inclusion (AFI) Executive Director Mr. Alfred Hannig highlighted on $24^{\text {th }}$ April 2013 progress in Financial Inclusion during the International Monetary Fund (IMF)-World Bank 2013 Spring Meetings: "Financial 
Inclusion is no longer a fringe subject. It is now recognized as an important part of the mainstream thinking on economic development based on country leadership."

The increasing attention that financial inclusion has been gaining requires precise attention to specific groups of the population that have been excluded historically from the formal financial sector either due to their income level, location, gender, or level of financial literacy. By doing so, there is a need to utilize the untapped potential of those individuals and enterprises currently excluded from the formal financial sector or underserved, and enable them to develop their capacity, enhance their human and physical capital, engage in activities that generate income, and manage risks associated with their lifestyles. The aim of financial inclusion goes beyond improved access to credit to include enhanced access to risk mitigation and savings products. The aim is to have a well-functioning financial system that allows individuals and companies to engage actively in the economy while protecting consumers' rights.

This paper aims first to address the issue of financial inclusion and provide information on the level of financial inclusion in different countries, mainly in developing countries by contructing a FII capturing the accessibility dimension as well as the usage and the quality dimensions of financial inclusion. Such an index aims at measuring the overall changes in financial inclusion and providing a complete picture of the current level of financial inclusion in several developing countries. Moreover, the key value addition stems from the attempt to use the constructed FII in a panel framework for 37 developing countries over a period of 10 years from 2009 to 2018 to assess empirically the impact of financial inclusion on the inflation rate using dynamic panel data analysis using the two-step system GMM methodology. Furthermore, the empirical findings will enrich the present literature by providing useful findings and insights for financial inclusion and inflation rate literature in general and concerning the developing countries in particular. Finally, the research outcome is also beneficial for the policymakers of the developing countries to implement the suitable policies about financial inclusion and provide scope for policy debate.

The rest of the study is organized as follows: the next section is devoted to a review of literature that investigated the impact of financial inclusion on inflation rate. The third section describes the data and the empirical methodology used. The empirical results are presented and analyzed in the fourth section. The concluding section summarizes the main findings and highlights the implications of the study.

\section{Literature Review}

This section provides some definitions of financial inclusion and deliberates the ways by which the increase in financial inclusion might affect the inflation rate in developing countries based on previous studies. 


\subsection{Financial Inclusion}

A definition of financial inclusion should address equality of access ${ }^{1}$ to financial services and information. No group should be deprived of access to financial services and information enjoyed by others, due to external circumstances out of their control. The Center for Financial Inclusion defined full financial inclusion as "A state in which everyone who can use them has access to a full set of quality financial services, at affordable prices, provided conveniently, and with respect and dignity" (Gardeva, 2010; Coppock, 2013).

United Nations (2006), in its book titled "Building Inclusive Financial Sector for Development," defined financial inclusion as "The access to credit for all "bankable" people and firms to insurance for all insurable people and firms and savings and payment services for everyone." The IMF defined financial inclusion as the planned and organized efforts aiming at making the financial services available for everyone, especially for the deprived and the poor. Also, the World Bank defined financial inclusion as affordable and useful financial products and services, accessible to individuals and businesses, meet their needs (insurance, transactions, payments, savings, and credit) and at the same time are delivered to all the individuals and businesses in the society responsibly and sustainably (World Bank, 2018).

Financial inclusion is a strategy that pursues to avoid the market friction that impedes the markets from operating in favor of the disadvantaged people. It offers complementary and incremental solutions to tackle the issue of poverty, to address the Millennium Development Goals (MDG's) set by the UN, and to promote inclusive development (Chibba, 2009).

Full financial inclusion means providing each household with access to a set of new financial services, including payments, savings, credit, and insurance, as well as sufficient financial education to assist customers in making correct and wise decisions. These financial products and services should be available, affordable, designed to meet the population's needs, and regulated to protect consumers (Goland, Bays, \& Chaia, 2010). On the other hand, the rejection of financial products and services and the conditions that lead to depriving either an individual or a group of the society, from the benefits of these services is called financial exclusion (Kumar \& Mishra, 2009).

In developing countries, there has been more recent regulation, to support the financial inclusion agenda through mandates as regulators tend to be more concerned with financial inclusion, such as "consumer protection, financial capability, and regulation of microfinance, promotion of savings, promotion of access to finance for Small and Medium Enterprises (SMEs), and promotion of rural finance." A possible explanation could be that richer countries already have higher levels of financial inclusion than other countries; as a result, they do not need to seek for higher levels of financial inclusion (Yorulmaz, 2012).

Financial inclusion strives to engage the population, which is excluded from

\footnotetext{
${ }^{1}$ Everyone must have the same financial opportunities.
} 
the financial system into the formal financial system to allow them to access financial services such as savings, payments, credit, transfers, and insurance (Hannig \& Jansen, 2010). In other words, financial inclusion aims to bring the population out of the financial system under its roof, to ensure that the banking services are available to everyone, especially the low-income groups, to facilitate allocating productive resources efficiently, and to deliver different financial services at affordable prices to financially excluded individuals and micro, small and medium-sized entrepreneurs (MSME) and consequently reach an inclusive financial system (Yorulmaz, 2013). There are several benefits of an inclusive financial system on a micro and macro level. On the micro-level, families are capable of organizing their income in a better way while having access to credit (loans). Also, microfinance permits them to plan their expenses and be able to pay for an educational plan, thus have the chance to enjoy a better life in the future. Moreover, by increasing the accessibility to credits, a country can encourage entrepreneurs, so they can start-up new small businesses, resulting in a higher national economic output (Blando, 2013). Shirin (2016) explained further that financial inclusion is not only about ensuring access to financial services, but access must also be appropriate. For access to be appropriate, it has to be transparent, fair, and cost-effective and through mainstream institutional players. Greater access and usage of financial services cannot be guaranteed by increasing access to deposit accounts, increasing the number of branches, and having a larger number of Automated Teller Machines (ATM).

The significance of financial inclusion has been recognized by developed economies as a strategic device to alleviate and reduce poverty levels and achieve the goal of inclusive growth. Not only does financial inclusion improves the wellbeing of their citizens and provide them with more opportunities, reduce the poverty level, and protects them against unexpected negative scenarios, but also it helps in reducing corruption, reducing tax evasion by reducing the size of the informal economy and providing greater transparency in financial transactions. Moreover, it ensures that domestic and foreign aid arrives effectively to the people who need it the most, reduces administrative costs, and improves efficiencies in government tasks like pension payments and tax collection. Last but not least, it increases security in a country as people would not need to move with large amounts of cash (Lochy, 2020).

\subsection{Financial Inclusion and Inflation Rate}

Limited literature investigated the impact of financial inclusion on inflation rate. Most of the studies have focused on testing the effect of financial inclusion on economic growth, poverty, and income inequality. Financial inclusion is crucial for central banks to stabilize the financial systems and to efficiently manage the monetary policy, as higher financial inclusion can significantly alter consumers' and firms' behavior. Since financial inclusion enables the participation of a larger sector of the economy in the formal financial system, therefore it creates a 
positive externality in the economy since it allows a more effective monetary policy implementation and transmission. Higher financial inclusion allows interest rates to become a useful policy tool; it also facilitates the mechanism through which Central Banks can stabilize price levels, according to Mehrotra and Yetman (2014). Since inclusion allows higher levels of consumption smoothing, households are then better able to respond to changes in interest rates through adjusting 19 their level of savings and loans. Higher financial inclusion can also encourage households to convert their savings into deposits and away from physical assets. Khan (2011) agreed that higher levels of financial inclusion make interest rates a relatively primary and robust policy tool. As financial inclusion increases, money stock starts to be converted from the currency in circulation to interest-bearing deposits in the banking system. This allows a large portion of the economic activity (i.e., broad money) to be under the control of interest rates. Khan (2011) argues the bigger the informal sector is, the harder it is for monetary policy to be implemented and transmitted, as the decisions of a larger number of households and small business owners will be independent without putting into consideration the central banks' monetary policy actions. Additionally, financial inclusion encourages people to move from a cash economy to a bank economy (cashless), so their financial transactions can be surveilled. Consequently, Anti-Money laundry guidelines can be efficiently implemented to the majority of financial transactions in the economy.

Mbutor and Uba (2013) tested the impact of financial inclusion on monetary policy in Nigeria between 1980 and 2012. The results supported the view that growing financial inclusion would improve the monetary policy effectiveness, as the ratio of total loans increases, the inflation will decrease. Mehrotra and Yetman (2014) used cross-sectional data for over 130 economies, using the Global Findex, and found out that financial inclusion has a positive effect on the ratio of output volatility to inflation volatlity under the condition that the central bank cares about both and sets monetary policy to optimize their trade-off.

Most of the previous empirical studies have investigated the implications of financial inclusion for certain central banks' policy parameters' rule and model stability (Bilbiie, 2008; Colciago, 2011; Gali, Lopez-Salido, \& Valles, 2004). Others have discussed the monetary policy efficacy (Di Bartolomeo \& Rossi, 2007). The few empirical studies that have tested the relationship between financial inclusion and monetary policy (Evans, 2016; Lapukeni, 2015; Lenka \& Bairwa, 2016; Mbutor \& Uba, 2013; Mehrotra \& Nadhanael, 2016). However, these empirical studies failed to address the issue of endogeneity that might exist between financial inclusion and monetary policy (inflation rate) (Lapukeni, 2015; Lenka and Bairwa, 2016; Mehrotra and Nadhanael, 2016).

The impact of financial inclusion on the monetary policy of the South Asian Association for Regional Cooperation (SAARC) countries from 2004-2013 was examined by Lenka and Bairwa (2016). The study constructed a FII, using PCA, to measure the accessibility of financial inclusion in the SAARC countries. Moreover, random effect model, fixed effect model, and panel-corrected standard error mod- 
el were used for the analysis. The empirical results of Generalized Least Square (GLS) estimation showed that the there is a significant negative association between financial inclusion and inflation rate. Also exchange rate and interest rate were found to be negatively associated with inflation rate in SAARC countries.

Moreover, El Sherif (2019) evaluated the impact of financial inclusion on the effectiveness of monetary policy in Egypt for 17 years from 2000 to 2017 using Vector Error Correction Model (VECM), Granger Causality tests, and basic trend analyses. The results showed that there is a negative relationship between financial inclusion and the inflation rate in Egypt. It was also found that a bidirectional relationship exists between financial inclusion and monetary policy where; financial inclusion significantly affects the monetary policy effectiveness, also monetary policy effectiveness affects financial inclusion in Egypt.

On the other hand, Evans (2016) empirically analyzed the impact of financial inclusion on the monetary policy effectiveness in a sample of 15 African countries for a period of 10 years from 2005 to 2014. The results indicated that financial inclusion has no significant impact on monetary policy effectiveness, on the contrary it is monetary policy effectiveness that causes financial inclusion.

Agoba, Sare and Bugri-Anarfo (2017) attempted to review the extant literature on financial inclusion, financial development innovation, and monetary policy. Literature between 2007 and 2015 was surveyed, and key themes in this field of study, methodologies adopted, and the geographical distribution of the studies was identified to be able to identify relevant gaps and direction for future research. The study recommended that the impact of financial inclusion on monetary policy using panel data needs to be assessed. In a similar study, Suman (2017) provided a systematic review of recent studies on financial inclusion around the world, and this review covered several areas of financial inclusion including policies and challenges, determinants and factors influencing financial inclusion, evaluation and measurement and finally covered the effects of financial inclusion on poverty, inequalities, monetary policy and economic growth of a country. Through this review, it was found out that most of the studies support the view that financial inclusion has a strong and positive impact on the economic growth and development rather than on monetary policy and financial stability. So, Suman (2017) recommended that the focus of future research and the gap to be filled should be concerning the impact of financial inclusion on monetary policy cross-country and regional using panel data.

From the abovementioned studies, it is clear that there is a gap that needs to be filled concerning the impact of financial inclusion on the inflation rate using panel data as only a few numbers of studies analyzed the impact of financial inclusion on monetary policy and most of them were applied on a single region or country and not a cross-country analysis.

\section{Data and Methodology}

This section is divided into two main subsections; subsection 3.1 elaborates the 
population and the sample size of this study and describes the selected sample. Moreover, the type of data and the method of data collection used are discussed. Subsection 3.2 discusses the methodology used in the study.

\subsection{Data}

This study is based on quantitative research. The dataset is a balanced panel comprising annual information on the inflation rate, financial inclusion indicators, and some control variables, exchange rate, lending interest rate, broad money, and official reserves for 37 developing countries over the period 2009-2018, thus totaling 370 observations. Data for all the indicators used are collected exclusively from secondary sources namely; Financial Access Survey 2019 (FAS) by the IMF, World Bank Group Doing Business (WBG-DB), World Development Indicators (WDI) by the World Bank, and the IMF. Several international published sources were used in collecting the data for all the variables, whether being dependent, control, or independent variables.

The independent variable in this study is financial inclusion. Since there is no concrete measure for financial inclusion, this study attempts to construct a new FII composed of three dimensions (access, usage, and quality) using the PCA method following Cámara and Tuesta, (2014). The data concerning the indicators used to measure each of the three dimensions are collected from the FAS 2019 and theWBG-DB. The construction of the FII is discussed in detail in the following subsection 3.2.1.

The dependent variable, the inflation rate $^{2}$, the control variables used in this study, as mentioned above, are exchange rate ${ }^{3}$, lending interest rate ${ }^{4}$, broad money $^{5}$, and official reserves ${ }^{6}$. All of these variables are obtained from the WDI by the World Bank, except the exchange rate that was obtained from the IMF.

According to the World Economic Situation and Prospects Report (WESP) 2020 by the UN (United Nations, 2020), there are 78 developing countries around the world. Out of the 78 developing countries, only 43 were found to be complete without any missing data for the financial inclusion indicators, so the FII of this study is measured using 43 developing countries. Due to the unavailability of other macroeconomic indicators data in several countries from the 43 , the sample of this study includes 37 developing countries after excluding the countries with missing data to assess the impact of FII on the inflation rate in developing countries. Table 1 below lists the $37^{7}$ developing countries included

\footnotetext{
${ }^{2}$ Measured as "a percentage of change in the average Consumer Price Index (CPI)."

${ }^{3}$ Local currency units per US dollar.

4"Is the bank rate that usually meets the short- and medium-term financing needs of the private sector. This rate is usually differentiated according to the creditworthiness of borrowers and the objectives of financing."

5"The sum of currency outside banks; demand deposits other than those of the central government; the time, savings, and foreign currency deposits of resident sectors other than the central government; bank and traveler's checks; and other securities such as certificates of deposit and commercial paper."

"Foreign exchange reserves including gold, billion USD."

${ }^{7}$ The 37 countries are from 6 different regions; Eastern Asia \& Pacific, South Asia, Europe \& Central Asia, Latin America \& Caribbean, Sub-Saharan Africa (SSA), and Middle East \& North Africa (MENA).
} 
Table 1. Sample of the study.

\begin{tabular}{lccccc}
\hline$\#$ & Country & $\#$ & Country & $\#$ & Country \\
\hline 1 & Algeria & 14 & Eswatini & 27 & Mauritius \\
2 & Argentina & 15 & Fiji & 28 & Mongolia \\
3 & Bahamas & 16 & Guatemala & 29 & Namibia \\
4 & Belize & 17 & Guyana & 30 & Nicaragua \\
5 & Bolivia & 18 & Honduras & 31 & Oman \\
6 & Botswana & 19 & India & 32 & Pakistan \\
7 & Brazil & 20 & Indonesia & 33 & Peru \\
8 & Brunei Darussalam & 21 & Jamaica & 34 & Samoa \\
9 & Chile & 22 & Jordan & 35 & South Africa \\
10 & Colombia & 23 & Kenya & 36 & Thailand \\
11 & Costa Rica & 24 & Lebanon & 37 & Trinidad and Tobago \\
12 & Dominican Republic & 25 & Malaysia & & \\
13 & Egypt, Arab Rep. & 26 & Maldives & & \\
\hline
\end{tabular}

Source: Prepared by the Author based on data from the WESP 2020.

in the sample of the study.

\subsection{Methodology}

Before assessing the impact of financial inclusion on the inflation rate, the extent of financial inclusion needs to be identified. The first step towards determining the extent of financial inclusion is to identify the indicators that can be used to measure the level of accessibility of financial services in a country. Policymakers need reliable information about the extent of the current financial inclusion prevaled to set policies and actions to increase the access and usage levels of financial services. This section is composed of 3 main subsections. The first subsection describes in detail the process of constructing a FII. The specification of the model used to assess the impact of financial inclusion (using the FII) on the inflation rate is explained in subsection 3.2.2, while the empirical methods used explained in subsection 3.2.3.

\subsubsection{Measuring Financial Inclusion}

Since countries are heterogeneous, the individual financial inclusion dimensions (access, usage, and quality) may not provide comparable outcomes across countries. That is, a country can perform better in one of the dimensions but not in others, and vice versa. Recent literature views financial inclusion as a multidimensional construct and proposes different parameters to measure the financial system inclusiveness to address this challenge. Several studies in the literature have focused on multidimensional aspects of financial inclusion (Amidzic, Massara, \& Mialou, 2014; Cámara \& Tuesta, 2014; Gupte, Venkataramani, \& Gupta, 2012; Park \& Mercado, 2018; Sharma, 2016; Yorulmaz, 2013). This study meas- 
ures the extent of financial inclusion across developing countries by constructing a new multidimensional financial inclusion index for developing countries before assessing the impact of financial inclusion on the inflation rate following the abovementioned studies in the literature.

Several variables could be theoretically relevant for inclusion in each of the three dimensions of financial inclusion for arriving at a comprehensive picture of the inclusive financial system across the countries. However, because the data for a number of these variables are usually not readily available, data availability constraints prevent from achieving this objective and their proxies are used to measure each dimension.

Just as no single conceptual definition of financial inclusion exists, no standard measure of the concept is universally accepted. Consequently, following the Financial Inclusion Indicators set, which was endorsed by G20 leaders in 2012 and established by the Global Partnership for Financial Inclusion (GPFI), the degree of financial inclusion in this study is determined by three dimensions: 1) access to financial services; 2) usage of financial services; and 3) the quality of the products and the service delivery. Including the usage and quality dimensions in the definition and measurement of financial inclusion in addition to the access dimension, is vital because it helps to overcome the often mistaken supposition that financial inclusion will only be achieved by merely offering enough access points savings products. Therefore issues of the frequency of use by individuals and the quality of financial services towards effectively meeting their needs are believed to provide more useful analytical results and explanations for financial inclusion.

Table 2 below summarizes the list of indicators used to compute the FII in this study. The indicators used are selected based on data mode and availability.

Table 2. Financial inclusion indicators.

\begin{tabular}{|c|c|c|}
\hline Dimension & Indicator & Source \\
\hline \multirow{4}{*}{ Access } & Number of bank branches per 100,000 adults & \multirow{8}{*}{$\begin{array}{l}\text { IMF-FAS } \\
\text { Database }\end{array}$} \\
\hline & Number of ATMs per 100,000 adults & \\
\hline & Number of branches per $1000 \mathrm{Km}^{2}$ & \\
\hline & Number of ATMs per $1000 \mathrm{Km}^{2}$ & \\
\hline \multirow{4}{*}{ Usage } & Number of deposit accounts with commercial banks per 1000 adults & \\
\hline & Number of loan accounts with commercial banks per 1000 adults & \\
\hline & Outstanding Deposits from commercial banks \% of GDP & \\
\hline & Outstanding Loans from commercial banks \% of GDP & \\
\hline Quality & $\begin{array}{l}\text { Credit Barriers } \\
\text { - Getting Credit: Depth of Credit Information Index (0 - 6) } \\
(2005-2014 \text { methodology) } \\
\text { - Getting Credit: Depth of Credit Information Index }(0-8) \\
(2015-2020 \text { methodology) }\end{array}$ & (WBG-DB) \\
\hline
\end{tabular}

Source: Prepared by the Author. 
Getting credit: Depth of credit information index, prepared by the WBG Doing Business (DB), will be used as an indicator for the quality dimension. This index measures the scope, coverage, and accessibility of credit information available through credit reporting service providers such as credit registries or credit bureaus. The index ranges from 0 to 6 based on the methodology in the DB 20052014 studies and ranges from 0 to 8 based on the methodology in the DB 20152020 studies. Since the methodology used to calculate the index from 2009-2014 is different from that used from 2015-2020, therefore this indicator cannot be used for the period from 2009-2018. As a way out for this problem, a dummy variable is created where 1 if the index score is $1-8$ and 0 if otherwise.

Considering the view proposed by Cámara and Tuesta (2014), the two-stage PCA method is applied as an indexing strategy to estimate the degree of financial inclusion. The calculation of the index and the derivation of the two-stage PCA involves the following steps:

\section{Step 1: Normalization of Values of Indicators}

There are significant variations across country-specific values of the different indicators of financial inclusion. Each indicator has been "normalized" in order to ensure better comparability of these data and to smooth out the different scales and transform the highly skewed indicators, the dataset is normalized using the Min-Max method. This process makes all the different indicators in an equal range between 0 and 1 , by subtracting the minimum value and dividing it by the range of the indicators' values (Le, Chuc, \& Taghizadeh-Hesary, 2019; Yorulmaz, 2018). The formula used for the normalization process is shown below in Equation (1):

$$
X_{i, d}=\frac{x_{i}-m_{i}}{M_{i}-m_{i}}
$$

where $x_{i}$ is the actual value of indicator $i, m_{i}$ is the minimum value of indicator $i$, and $M_{i}$ is the maximum value of dimension $i . X_{i, d}$ is the standardized value of indicator $i$ of dimension $d$. The normalized indicator takes a value 0 representing the lower end of the country's scale of financial inclusion, while 1 indicates the top end of the country's degree of inclusion for all the individual categories of indicators, and which varies between 0 and 1 for all other countries. Based on the abovementioned normalized figures, PCA has been applied to calculate the FII for every country.

\section{Step 2: First Stage PCA}

The first stage of PCA aims to estimate the dimensions, that is, the three unobserved endogenous variables $\mathrm{DiA}, \mathrm{DiU}$, and $\mathrm{DiQ}$ and the parameters in the following equations:

$$
\begin{aligned}
& D_{i}^{A}=\gamma_{1} \mathrm{AC} 1+\gamma_{2} \mathrm{AC} 2+\gamma_{3} \mathrm{AC} 3+\gamma_{4} \mathrm{AC} 4+\varepsilon_{i} \\
& D_{i}^{U}=\alpha_{1} \mathrm{US} 1+\alpha_{2} \mathrm{US} 2+\alpha_{3} \mathrm{US} 3+\alpha_{4} \mathrm{US} 4+\varepsilon_{i}
\end{aligned}
$$

where: $\gamma$ and $\alpha$ are coefficients for the equations to be estimated for both equations, AC 1: Number of commercial bank branches per $1000 \mathrm{~km}^{2}$, AC 2: Number 
of commercial bank branches per 100,000 adults, AC 3: Number of ATMs per $1000 \mathrm{~km}^{2}$, AC 4: Number of ATMs per 100,000 adults, US 1: Number of deposit accounts with commercial banks per 1000 adults, US 2: Number of loans accounts with commercial banks per 1000 adults, US 3: Outstanding deposits from commercial banks as a \% of GDP, US 4: Outstanding loans from commercial banks as a $\%$ of GDP, and $\varepsilon_{\mathrm{i}}$ is the error term.

\section{Step 3: Second Stage PCA}

After obtaining the dimension indices, another PCA is applied to derive the dimension weights for the overall financial inclusion. Following Cámara and Tuesta (2014), it is assumed that the FII can be expressed as a linear function as follows:

$$
F I I_{i}=w_{1} D_{i}^{a}+w_{2} D_{i}^{u}+w_{3} D_{i}^{q}+\varepsilon_{i}
$$

where $F I I_{i}$ : Financial Inclusion Index, $D_{i}^{a}, D_{i}^{u}$, and $D_{i}^{q}$ capture the access, usage, and quality dimensions of financial inclusion, respectively. The subscript $i$ denotes the country and $\varepsilon_{i}$ is the error term. Equation 4 states that the index of financial inclusion for the sample of the study of 43 developing countries is a weighted average of individual dimensions.

\subsubsection{Model Specification}

The inflation rate was regressed against the financial inclusion index and other country-level control variables for a sample of 37 developing countries from 2009-2018, to assess if financial inclusion has a significant negative impact on the inflation rate in developing countries. Therefore the econometric model used in the empirical analysis to measure the impact of financial inclusion on inflation rate is as follows:

$$
I N F_{i t}=\beta_{0}+\beta_{1} F I I_{i t}+\beta_{2} X_{i t}+\varepsilon_{i t}
$$

where $\beta_{0}$ is the intercept coefficient estimate, $I N F_{i t}$ inflation rate, $F I_{i i}$ Financial Inclusion Index across countries at time $t, X_{i t}$ stands for other macroeconomic variables as control variables, $\varepsilon_{i t}$ is the error term of the model, $i$ and $t$ indicate country and year, respectively.

This empirical model is improved with the control variables, foreign exchange rate, lending interest rate, broad money, and official reserves to avoid omitted variable bias due to the point of view that financial inclusion might not alone stimulate inflation rate. The specific form of Equation (5) that is used for performing regression is given by Equation (6):

$$
I N F_{i t}=\beta_{0}+\beta_{1} F I I_{i t}+\beta_{2} E X R_{i t}+\beta_{3} I R_{i t}+\beta_{4} B M_{i t}+\beta_{5} R E S_{i t}+\varepsilon_{i t}
$$

where $E X R_{i t}$ Foreign Exchange rate, $I R_{i t}$ Interest Rate, $B M_{i t}$ Broad Money (Money Supply), $R E S_{i t}$ Official Reserves.

The rationale behind the above model is that financial inclusion will enable monetary policy to extend its reach to the financially excluded and aid policymakers to make better predictions of movements in inflation rate. From a policy perspective, increased participation will expand the value of the overall financial 
system, making monetary policy more effective. As the share of the formal financial sector increases through greater financial inclusion, it yields a critical positive externality by making monetary policy more efficient in reaching its objective, which is price stability, in other words, decrease the inflation rate. In other words, greater financial inclusion could strengthen the effort of the central bank in maintaining price stability through interest rate, thereby making monetary policy effective.

This empirical model is improved with the following control variables; foreign exchange rate following Mbutor and Uba (2013); Lenka and Bairwa (2016) and El Sherif (2019). Broad money as a percentage of GDP is also used as a control variable following Evans (2016) and El Sherif (2019). Moreover, the lending interest rate is used as a control variable following Mbutor and Uba (2013); Evans (2016); Lenka and Bairwa (2016) and El Sherif (2019). The increase in the foreign exchange rate leads to cheaper domestic goods for foreign consumers, resulting in an increase in exports and total demands and prices. The increase in the foreign exchange price raises the inflation rate (Monfared \& Akın, 2017), therefore the coefficient of the exchange rate is expected to be positive. As for the interest rate, as interest rates are reduced, more people are able to borrow more money. The result is that consumers have more money to spend, causing the economy to grow and inflation to increase; therefore, the coefficient of interest rate is expected to be negative. The money supply is the amount of money available in a country. Monetarists believe that the source of inflation is fundamentally derived from the growth rate of the money supply and that a rapid increase in money supply leads to a rapid increase in inflation (Kiganda, 2014), therefore the coefficient of broad money is expected to be positive. According to Khan (1979) and the quantity theory of money, growth in the international reserves causes a rise in the inflation rate, therefore the coefficient of reserves is expected to be positive.

\subsubsection{Empirical Methodology}

This subsecion discusses the empirical tests used in the study to assess the impact of financial inclusion on inflation rate in developing countries after constructing the FII for the countries under study.

\section{- Descriptive Statistics}

Before starting the regression analysis, summary statistics are performed to show the nature of the data in general, listing the mean, standard deviation, minimum and maximum values for each of the selected variables used in the model.

\section{- Diagnostic Tests}

Before conducting regression analysis, multicollinearity, heteroscedasticity, autocorrelation, and endogeneity assumptions should be verified to be able to use the best technique for the regression analysis. Variance Inflation Factor (VIF) is used to check for the existence of multicollinearity, Wooldridge test is used to test for the presence of autocorrelation, Likelihood ratio test is used to test for the heteroscedasticity problem, and Davidson-MacKinnon test is used to test for 
the problem of endogeneity.

\section{- $G M M$}

This study adopted the two-step system GMM estimation, outlined in Arellano and Bover (1995) and fully developed in Blundell and Bond (1998), which incorporates the finite sample corrected standard errors introduced by Windmeijer (2005). Moreover, the system GMM estimator provides consistent and efficient estimates, overcomes the endogeneity problem, and is a better fit for panel studies, having fewer time points and greater numbers of individuals $(\mathrm{N}>\mathrm{T})$. Blundell and Bond (1998) found that system GMM has significantly smaller bias and generates more precise estimates compared to difference GMM. System GMM uses a lagged dependent variable model to assess the dynamic nature of both dependent and independent variables in the model.

Furthermore, in recent years, several studies including Ghosh (2011); Andrianaivo and Kpodar (2012); Mehrotra and Yetman (2014); Kim, Yu and Hassan (2017); Minhaj et al. (2019); Akanbi et al. (2020) and Burguillos and Cassimon (2020) used the two-stage system GMM to estimate the impact of financial inclusion on macroeconomic indicators such economic growth, inflation rate, and unemployment rate.

As recommended by Roodman (2006) the inclusion of time dummies makes the following assumption more valid-"the autocorrelation test and the robust estimates of the coefficient standard errors assume no correlation across individuals in the idiosyncratic disturbances." The following Equation (7) is used to investigate the impact of financial inclusion on the dependent variable; inflation rate using the two-step system GMM estimator:

$$
\begin{aligned}
I N F_{i, t}= & \beta_{0}+\beta_{1} I N F_{i, t-1}+\beta_{2} F I I_{i, t}+\beta_{3} I R_{i, t}+\beta_{4} E X R_{i, t} \\
& +\beta_{5} B M_{i, t}+\beta_{6} R E S_{i, t}+\alpha_{t}+\varepsilon_{i, t}
\end{aligned}
$$

where: $I N F_{i, t-1}$ the lagged inflation rate, $\alpha_{t}$ represents yearly dummies to control time effects. It is important to include time effects to capture macro-economic factors that are beyond country control.

\section{Empirical Results and Discussion}

This section covers the analysis of data and interpretation of the results. It is divided into 4 subsections, first the FII of the 37 countries from 2009 to 2018 is presented, next the results of the diagnostic tests are provided in subsection 4.2 to detect model misspecification and guide for model improvements. Moreover, the descriptive statistics results and the GMM results are discussed in subsections 4.3 and 4.4 respectively.

\subsection{Developing FII Using PCA}

In this subsection, the measurement model for developing FII is conducted using STATA version 16. The measurement model depends on three main dimensions, which are: Access, Usage, and Quality. Before using PCA, indicators of each dimension are normalized to have values between zero and one to ensure 
that the scale in which they are measured is immaterial. Where zero indicates financial exclusion, and one indicates financial inclusion ${ }^{8}$.

\subsubsection{Validity and Reliability Results}

Table 3 below shows the KMO measure values for all the nine indicators to identify the adequate indicators to be included to develop the FII.

Table 4 below shows the KMO values for the final indicators to be added to the index after deleting four items, as mentioned above. It could be observed that quality had not been included due to weak item loading (Item Loading < 0.49). Also, two items had been deleted from access, which are AC1 (Number of commercial bank branches per $1000 \mathrm{~km}^{2}$ ) and AC3 (Number of ATMs per 1000 $\mathrm{km}^{2}$ ), and one item had been deleted from usage, which is US1 (Number of deposit accounts with commercial banks per 1000 adults). Other items had loading greater than 0.49 and been included. Therefore the FII will include a total of 5 indicators, two indicators under the access dimension, and three indicators under the usage dimension.

Regarding the items included, it could be observed in Table 5 that all AVE

Table 3. KMO values for all indicators.

\begin{tabular}{cl}
\hline Variable & KMO \\
\hline AC 1 & 0.4357 \\
AC 2 & 0.7201 \\
AC 3 & 0.4641 \\
AC 4 & 0.7591 \\
US 1 & 0.8080 \\
US 2 & 0.4462 \\
US 3 & 0.7629 \\
US 4 & 0.8164 \\
Q 1 & 0.4781 \\
Overall & 0.6293 \\
\hline
\end{tabular}

Source: Calculated by the author on STATA 16.

Table 4. KMO values for the final indicators included in the index.

\begin{tabular}{cl}
\hline Variable & KMO \\
\hline AC 2 & 0.7940 \\
AC 4 & 0.6703 \\
US 1 & 0.7515 \\
US 3 & 0.5701 \\
US 4 & 0.6117 \\
Overall & $\mathbf{0 . 6 4 9 8}$ \\
\hline
\end{tabular}

Source: Calculated by the author on STATA 16.

${ }^{8}$ See section 3.2.1. 
values are greater than $50 \%$, meaning that there is no problem with convergent validity. AVE value is also greater than the SC value $(0.733>0.196)$ and $(0.781>$ 0.196); therefore, there is no problem with discriminant validity9. Cronbach's alpha is greater than $0.7^{10}$, implying that the data under study have adequate validity and reliability after deleting the mentioned items.

Table 7 below presents the descriptive statistics about the indicators used to measure FII. As shown in the Table below the number of observations for US1 is 428 as there were 2 missing observations for this indicator.

\subsubsection{First-Stage PCA Results}

Through the PCA method, eigenvalues of each sub-index are calculated, and the latent variables: access $\left(D_{i}^{A}\right)$ and usage $\left(D_{i}^{U}\right)$, are estimated as shown below in Table 8. The highest eigenvalue of the components retains more standardized variance, among others, and an eigenvalue greater than 1 is considered for the

Table 5. Reliability and validity for FII dimensions.

\begin{tabular}{cccc}
\hline FII Dimensions & Items & AVE & Cronbach's Alpha \\
\hline Access & AC 2 & 0.733 & \\
& AC 4 & & \\
Usage & US 1 & 0.7910 \\
& US 2 & & 0.781 \\
\end{tabular}

Source: Calculated by the author on STATA 16.

Table 6. Squared correlations (SC).

\begin{tabular}{ccc}
\hline & Access & Usage \\
\hline Access & 1.000 & \\
Usage & 0.196 & 1.000 \\
\hline
\end{tabular}

Source: Calculated by the author on STATA 16.

Table 7. Descriptive statistics for financial inclusion indicators.

\begin{tabular}{cccccc}
\hline Variable & Observation & Mean & Standard Deviation & Min & Max \\
\hline Access & & & & & \\
AC 2 & 430 & 15.437 & 11.046 & 1.299 & 71.212 \\
AC 4 & 430 & 40.398 & 27.606 & 1.531 & 133.791 \\
Usage & & & & & \\
US 1 & 428 & 1071.303 & 570.517 & 68.695 & 2828.528 \\
US 3 & 430 & 54.636 & 41.625 & 8.09 & 250.274 \\
US 4 & 430 & 44.571 & 24.642 & 5.306 & 118.136 \\
\hline
\end{tabular}

Source: Calculated by the author on STATA 16.

${ }^{9}$ See Table 6.

${ }^{10}$ See Table 5. 
analysis (Nguyen, 2020). Table 8 shows the results of the first-stage PCA. It can be seen that the eigenvalues of the principal components for the two dimensions in the corresponding order are: $1.35 ; 0.64$ (Access) and 2.056;0.703;0.236 (Usage). Except for the first principal (component 1 of the two dimensions), no other principal components have an eigenvalue greater than 1 . Therefore, the first component only is taken for analysis, and the dimensions are estimated by using the weights assigned to the first principal component of each dimension.

Table 9 shows the extracted weights for each of the five indicators. Accordingly, regarding the access dimension, the weights assigned to the first component are 0.7071 for the number of bank branches per 100,000 adults (AC 2) indicator; 0.7071 for the number of ATMs per 100,000 adults (AC 4) indicator. Meanwhile, for the usage dimension, the Outstanding Loans (US 4) indicator has a higher weight $(0.6427)$ than the Outstanding deposits (US 3) indicator (0.5887) and Deposit Accounts (US 1) indicator (0.4903). By assigning the above-extracted weights to Equations (2) and $(3)^{11}$; the following Equations (8) and (9) are derived for the access and usage dimensions, respectively:

$$
\begin{gathered}
D_{i}^{A}=0.7071 \mathrm{AC}_{2}+0.7071 \mathrm{AC}_{4}+\varepsilon_{i} \\
D_{i}^{U}=0.4903 \mathrm{US}_{1}+0.5887 \mathrm{US}_{3}+0.6427 \mathrm{US}_{4}+\varepsilon_{i}
\end{gathered}
$$

Table 8. Principal components estimates for sub-indices.

\begin{tabular}{ccccc}
\hline Component & Eigenvalue & Difference & Proportion & Cumulative \\
\hline Access Dimension & & & & \\
Component 1 & 1.35231 & 0.704628 & 0.6762 & 0.6762 \\
Component 2 & 0.647686 &. & 0.3238 & 1.0000 \\
Usage Dimension & & & & \\
Component 1 & 2.05967 & 1.35578 & 0.6866 & 0.6866 \\
Component 2 & 0.703884 & 0.467434 & 0.2346 & 0.9212 \\
Component 3 & 0.23645 &. & 0.0788 & 1.0000 \\
\hline
\end{tabular}

Source: Calculated by the author using PCA on STATA 16.

Table 9. Scoring coefficients for orthogonal varimax rotation (Weights).

\begin{tabular}{ccc}
\hline Variable & Component 1 & Unexplained \\
\hline Access Dimension & & 0 \\
AC 2 & 0.7071 & 0 \\
AC 4 & 0.7071 & \\
Usage Dimension & & 0 \\
US 1 & 0.4903 & 0 \\
US 2 & 0.5887 & 0 \\
US 4 & 0.6427 & 0 \\
\hline
\end{tabular}

Source: Calculated by the author using PCA on STATA 16.

${ }^{11}$ See section 3.2.1. 
The average value results of FI indicators by dimension are shown in the below Table 10.

\subsubsection{Second Stage PCA Results}

In the second stage, by applying the same procedure described in the first stage, the PCA method is applied to the two sub-indices (access and usage) to calculate Table 10. Financial inclusion indicators of countries by dimension-results of first-stage PCA.

\begin{tabular}{|c|c|c|c|c|c|}
\hline Country & Access Mean & Usage Mean & Country & Access Mean & Usage Mean \\
\hline Algeria & 0.232 & 0.456 & India & 0.358 & 0.3989 \\
\hline Argentina & 0.276 & 0.324 & Indonesia & 0.348 & 0.4370 \\
\hline The Bahamas & 0.212 & 0.312 & Jamaica & 0.181 & 0.2279 \\
\hline Belize & 0.253 & 0.281 & Jordan & 0.230 & 0.3634 \\
\hline Bolivia & 0.275 & 0.329 & Kenya & 0.354 & 0.4152 \\
\hline Botswana & 0.236 & 0.265 & Lebanon & 0.276 & 0.5092 \\
\hline Brazil & 0.246 & 0.426 & Malaysia & 0.288 & 0.3575 \\
\hline Brunei Darrusalam & 0.207 & 0.328 & Maldives & 0.282 & 0.3440 \\
\hline Cameroon & 0.201 & 0.266 & Mauritius & 0.238 & 0.4616 \\
\hline Chile & 0.230 & 0.325 & Mongolia & 0.311 & 0.3212 \\
\hline Colombia & 0.350 & 0.321 & Namibia & 0.299 & 0.3949 \\
\hline Costa Rica & 0.238 & 0.451 & Nicaragua & 0.364 & 0.4840 \\
\hline Dominican Republic & 0.176 & 0.262 & Oman & 0.284 & 0.4256 \\
\hline Ecuador & 0.275 & 0.296 & Pakistan & 0.362 & 0.4186 \\
\hline Egypt & 0.287 & 0.351 & Panama & 0.264 & 0.4018 \\
\hline El Salvador & 0.201 & 0.270 & Peru & 0.243 & 0.3577 \\
\hline Equatorial Guinea & 0.259 & 0.489 & Samoa & 0.272 & 0.3378 \\
\hline Eswatini & 0.297 & 0.399 & Saudi Arabia & 0.253 & 0.4683 \\
\hline Fiji & 0.197 & 0.301 & South Africa & 0.246 & 0.2651 \\
\hline Guatemala & 0.314 & 0.348 & Thailand & 0.303 & 0.4960 \\
\hline Guyana & 0.322 & 0.456 & $\begin{array}{c}\text { Trinidad and } \\
\text { Tobago }\end{array}$ & 0.313 & 0.4883 \\
\hline Honduras & 0.266 & 0.415 & & & \\
\hline
\end{tabular}

Source: Calculated by the author using PCA on STATA 16. 
their weights in the overall FII. The following Table 11 shows the results of principal components estimates for the composite FII. The eigenvalues of the two principal components, respectively are 1.40 , and 0.599 . This shows that only the first component has an eigenvalue greater than 1 , so it is taken to find the weights assigned to the principal components.

Similar to the method in the first phase, weights for the two dimensions are calculated. Table 12 below shows that the PCA assigned equal weights to the access and usage dimensions (0.7071).

By assigning the above-extracted weights to Equation $(4)^{12}$; the following Equation (10) is derived for the overall FII, respectively:

$$
F I I_{I}=0.7071 D_{I}^{A}+0.7071 D_{I}^{U}+\varepsilon_{i}
$$

By doing so, the overall FII for developing countries is estimated, as shown below in Table 13.

Table 13 shows the computed values for the FII according to equation 10 for 43 developing countries in the period from 2009 to 2018. It could be observed that the highest value of FII (99.29) was by Mauritius in 2014, but afterward, the score started to decline to reach nearly the same value it was in 2009, meaning that from 2009 to 2018, Mauritius level of FI remained almost the same, while Lebanon had the highest FI value (95.68) in 2018.

On the other hand, it could be observed that the lowest value of FII ( 0.33 and 0.34) by Equatorial Guinea and Cameroon, respectively, in 2009. Nevertheless, there was progress in the level of FI in these two countries to reach 13.81 and 14.62, respectively, in 2018. The progress in Cameroon can be due to that he value of mobile banking transactions as a percentage of GDP increased from 0.08\% in 2013 to $4.50 \%$ in 2016, and then to $30.24 \%$ in 2018 in Cameroon; this reflects the importance of this phenomenon, and further explains the growth rates observed in this country (IMF, 2019).

The greatest improvement in the FII from 2009 to 2018 was by Kenya, followed by Peru. The FII in 2009 in Kenya was 8.29 and increased by 29.31 points

Table 11. Principal component estimates for the overall FII.

\begin{tabular}{ccccc}
\hline Component & Eigenvalue & Difference & Proportion & Cumulative \\
\hline Component 1 & 1.40096 & 0.801928 & 0.7005 & 0.7005 \\
Component 2 & 0.599036 & & 0.2995 & 1.0000 \\
\hline
\end{tabular}

Source: Calculated by the author using PCA on STATA 16.

Table 12. Scoring coefficients (weights assigned to access and usage).

\begin{tabular}{ccc}
\hline Variable & Component 1 & Unexplained \\
\hline Access & 0.7071 & 0 \\
Usage & 0.7071 & 0 \\
\hline
\end{tabular}

Source: Calculated by the author using PCA on STATA 16.

${ }^{12}$ See section 3.2.1. 
Table 13. FII values computed for the period 2009 to 2018.

\begin{tabular}{|c|c|c|c|c|c|c|c|c|c|c|c|}
\hline \multirow{2}{*}{ Country } & \multicolumn{10}{|c|}{ Year } & \multirow{2}{*}{ Mean } \\
\hline & 2009 & 2010 & 2011 & 2012 & 2013 & 2014 & 2015 & 2016 & 2017 & 2018 & \\
\hline Algeria & 11.69 & 11.38 & 11.11 & 11.39 & 12.58 & 14.57 & 15.70 & 15.54 & 16.40 & 16.21 & 13.66 \\
\hline Argentina & 25.73 & 27.05 & 29.06 & 31.76 & 33.27 & 35.74 & 38.16 & 40.15 & 42.40 & 44.66 & 34.80 \\
\hline The Bahamas & 56.47 & 54.04 & 55.46 & 52.94 & 56.30 & 55.66 & 52.97 & 56.71 & 52.74 & 53.58 & 54.69 \\
\hline Belize & 35.15 & 34.34 & 33.84 & 33.17 & 33.28 & 31.49 & 30.19 & 31.34 & 29.75 & 30.83 & 32.34 \\
\hline Bolivia & 22.23 & 23.35 & 25.15 & 26.68 & 28.74 & 32.10 & 35.17 & 37.42 & 39.73 & 40.42 & 31.10 \\
\hline Botswana & 26.75 & 25.61 & 24.40 & 26.73 & 26.80 & 28.64 & 30.06 & 28.25 & 28.35 & 30.46 & 27.61 \\
\hline Brazil & 46.30 & 48.75 & 51.23 & 62.30 & 65.03 & 65.27 & 64.16 & 68.74 & 66.68 & 66.31 & 60.48 \\
\hline Brunei Darussalam & 52.84 & 48.32 & 46.52 & 53.36 & 51.03 & 58.19 & 60.61 & 58.80 & 57.00 & 56.82 & 54.35 \\
\hline Cameroon & 0.34 & 0.76 & 1.32 & 1.26 & 8.48 & 8.51 & 9.46 & 9.64 & 9.63 & 14.62 & 6.40 \\
\hline Chile & 60.82 & 61.54 & 65.17 & 67.73 & 68.01 & 70.61 & 71.32 & 71.27 & 71.04 & 72.20 & 67.97 \\
\hline Colombia & 34.58 & 35.36 & 37.13 & 39.29 & 41.33 & 45.06 & 47.14 & 48.00 & 48.77 & 49.52 & 42.62 \\
\hline Costa Rica & 46.69 & 46.25 & 49.41 & 50.63 & 56.14 & 59.68 & 57.97 & 62.69 & 65.16 & 66.86 & 56.15 \\
\hline Dominican Republic & 29.54 & 30.35 & 31.36 & 32.20 & 34.40 & 36.88 & 39.45 & 40.56 & 40.75 & 40.49 & 35.60 \\
\hline Ecuador & 27.15 & 29.27 & 27.87 & 28.09 & 30.03 & 33.32 & 33.10 & 34.34 & 34.63 & 35.25 & 31.30 \\
\hline Egypt & 23.55 & 24.79 & 25.24 & 24.35 & 25.37 & 28.75 & 30.67 & 36.51 & 36.67 & 36.23 & 29.21 \\
\hline El Salvador & 43.53 & 42.46 & 42.21 & 42.36 & 44.04 & 45.17 & 45.96 & 47.33 & 49.93 & 50.54 & 45.35 \\
\hline Equatorial Guinea & 0.33 & 0.50 & 0.78 & 1.27 & 1.60 & 2.06 & 11.57 & 12.53 & 13.20 & 13.81 & 5.76 \\
\hline Kingdom of Eswatini & 20.01 & 20.81 & 21.84 & 22.81 & 22.38 & 27.53 & 27.51 & 27.17 & 26.72 & 28.39 & 24.52 \\
\hline Fiji & 35.32 & 35.77 & 35.99 & 35.76 & 38.26 & 41.91 & 44.44 & 47.06 & 37.99 & 37.78 & 39.03 \\
\hline Guatemala & 39.35 & 41.67 & 43.73 & 45.91 & 48.62 & 51.74 & 52.45 & 51.82 & 50.73 & 47.25 & 47.33 \\
\hline Guyana & 13.95 & 14.74 & 15.43 & 16.15 & 16.76 & 16.73 & 16.57 & 16.04 & 28.78 & 28.73 & 18.39 \\
\hline Honduras & 35.98 & 34.80 & 36.30 & 38.44 & 39.78 & 42.53 & 42.60 & 43.31 & 43.24 & 44.37 & 40.14 \\
\hline India & 36.70 & 37.93 & 40.08 & 42.30 & 44.78 & 49.01 & 51.90 & 54.27 & 55.78 & 56.14 & 46.89 \\
\hline Indonesia & 25.96 & 26.53 & 30.63 & 36.55 & 40.87 & 42.02 & 43.06 & 44.32 & 48.25 & 49.13 & 38.73 \\
\hline Jamaica & 22.53 & 21.81 & 21.46 & 22.54 & 23.11 & 23.80 & 35.63 & 37.91 & 43.17 & 44.93 & 29.69 \\
\hline Jordan & 37.67 & 36.26 & 36.31 & 36.44 & 35.97 & 35.33 & 36.02 & 37.24 & 37.81 & 49.74 & 37.88 \\
\hline Kenya & 8.29 & 10.38 & 11.78 & 12.26 & 15.28 & 19.07 & 21.09 & 34.24 & 34.66 & 37.60 & 20.46 \\
\hline Lebanon & 83.60 & 87.87 & 89.83 & 90.08 & 90.02 & 92.25 & 93.48 & 95.67 & 97.01 & 95.68 & 91.55 \\
\hline Malaysia & 71.96 & 72.23 & 73.65 & 75.26 & 77.54 & 77.82 & 76.77 & 75.48 & 74.41 & 74.28 & 74.94 \\
\hline Maldives & 77.82 & 74.41 & 49.81 & 58.62 & 60.91 & 65.04 & 67.64 & 75.36 & 83.53 & 87.91 & 70.11 \\
\hline Mauritius & 87.42 & 91.53 & 92.59 & 94.64 & 97.60 & 99.29 & 97.45 & 95.89 & 94.23 & 86.80 & 93.74 \\
\hline Mongolia & 36.48 & 37.80 & 44.68 & 48.26 & 54.47 & 57.58 & 58.50 & 66.06 & 63.59 & 67.72 & 53.51 \\
\hline Namibia & 33.90 & 35.08 & 36.39 & 35.41 & 36.77 & 40.92 & 42.82 & 61.45 & 54.86 & 53.23 & 43.08 \\
\hline Nicaragua & 21.36 & 20.67 & 21.05 & 21.87 & 23.30 & 25.35 & 27.88 & 29.67 & 30.49 & 28.62 & 25.03 \\
\hline Oman & 25.35 & 27.88 & 29.67 & 18.73 & 19.34 & 20.34 & 24.38 & 25.65 & 30.49 & 28.62 & 25.04 \\
\hline
\end{tabular}




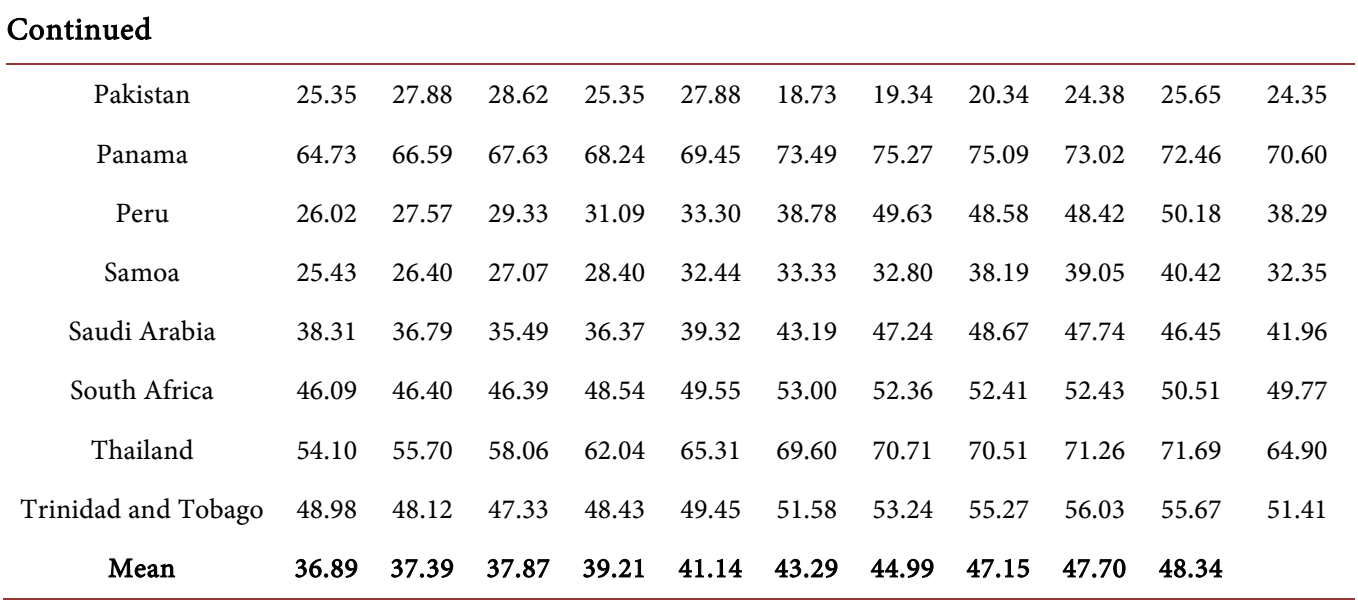

Source: Calculated by the author on STATA 16.

to reach a score of 37.6 in 2018. This improvement can be due to the M-Pesa as an example of financial technology solutions adopted in Kenya. As for Peru in 2009, the FII was 26 and increased by 24.16 points to reach 50.18 in 2018 . The reason behind this advancement in the level of financial inclusion is due to that Peru launched its National Financial Inclusion Strategy in July 2015 and has set an ambitious goal to expand and accelerate financial access and inclusion to 50\% of adults by the end of 2018 and then to at least $75 \%$ of adults by the end of 2021 (World Bank, 2015).

The lowest change in the level of financial inclusion from 2009 to 2018 was found in Belize and The Bahamas. The FII decreased in these two countries within the ten years, where the FII in Belize was 35.15 in 2009 and declined to reach 30.83 in 2018. Belize did not have a national financial inclusion strategy within the period of the study; its National Financial Inclusion Strategy was launched in September 2019 by the Central Bank of Belize. As for The Bahamas, the FII was 56.47 and declined by almost 3 points to reach 53.58 in 2018. The Bahamas Central Bank's governor mentioned that although The Bahamas enjoys the $35^{\text {th }}$ highest density of bank branches in the world and the $15^{\text {th }}$ highest density of ATMs in the world relative to the size of the population, but financial access is very uneven. He specified that the reason behind this might be due to that the basic banking services are not available at many of the rural island communities. Also, the high costs of providing banking services through traditional physical channels have further lessened this access. Moreover, affordability of access is more constrained in property insurance markets, where financial vulnerability is heightened because of the increasing frequency and intensity of hurricanes (Hartnell, 2019).

\subsection{Descriptive Statistics}

A preliminary step to the inferential analysis is the descriptive analysis presented in Table 14 below for all the variables used in the Model. The average inflation rate from 2009 to 2018 across the 37 developing countries is $4.77 \%$. The maxi- 
mum inflation rate was $34.28 \%$ in Argentina in 2018. Argentina's is from the top five countries with the highest inflation rates in the world after Venezuela, Zimbabwe, South Sudan, and Sudan (these countries are not included in the sample due to the unavailability of data). The rise in the inflation rate in 2016 to $25 \%$ was forced by removing distortionary price subsidies that had previously been used to disguise the real inflation rate; it finally jumped back up to $34.28 \%$ in 2018. On the other hand, the lowest inflation rate $(-3.7 \%)$ was in Lebanon in 2015. A negative inflation rate means that the general price level is declining, and consumer prices are getting cheaper; this is known as deflation.

\subsection{Diagnostics Tests Results}

Normality: Table 15 below shows the joint test for normality on each component of the error term and their p-values. The joint test for normality in the remainder component (e) is found to be symmetric as the null hypothesis is accepted with a p-value 0.311 . Also the joint test for normality in the country level component $(\mathrm{u})$ is found to be symmetric since the p-value greater than 0.05 , therefore the null hypothesis is accepted with a p-value 0.135 , indicating that the data in Model 2 is symmetric and normally distributed. The acceptance is stronger for the remainder component (e) than for the country specific component (u).

Multicollinearity: it could be observed that the VIFs of the variables in the below Table 16 FII, lending interest rate, foreign exchange rate, broad money, and foreign exchange reserves are less than 5 . This outcome implies that there is no problem of multicollinearity between the independent variables for the Model.

Autocorrelation: To test for the existence of autocorrelation, the Wooldridge test is applied. Results, as shown in the below Table 17, reveal that the probability

Table 14. Descriptive statistics results.

\begin{tabular}{cccccc}
\hline Variables & Observations & Mean & Standard Deviation & Min & Max \\
\hline Inflation Rate & 370 & 4.77 & 4.294 & -3.749 & 34.28 \\
FII & 370 & 0.438 & 0.199 & 0.083 & 0.993 \\
Interest Rate & 370 & 11.949 & 6.907 & 4.147 & 52.1 \\
Foreign Exchange Rate & 370 & 515.32 & 1923.862 & 0.38 & $14,236.94$ \\
Broad Money & 370 & 67.838 & 39.345 & 24.073 & 259 \\
Foreign Exchange Reserves & 370 & 44.609 & 83.299 & 0.1 & 412.61 \\
\hline
\end{tabular}

Source: Calculated by the author on STATA 16.

Table 15. Panel data normality test results.

\begin{tabular}{cccc}
\hline \multicolumn{2}{c}{ Joint test for Normality on $\mathrm{e}$} & \multicolumn{2}{c}{ Joint test for Normality on $\mathbf{u}$} \\
\hline $\mathrm{chi}^{2}(2)$ & Prob $>\mathrm{chi} 2$ & $\mathrm{chi}^{2}(2)$ & Prob > chi2 \\
\hline 1.35 & 0.311 & 3.61 & 0.135 \\
\hline
\end{tabular}

Source: Calculated by the author on STATA 16. 
value is significant and less than 0.05 . Therefore, the null hypothesis is rejected, and it can be concluded that the Model has an autocorrelation problem.

Heteroscedasticity: To test for the existence of heteroscedasticity, the likelihood ratio test is used. The result shows that the probability value is significant (less than 0.05), and the null hypothesis is rejected. Thus, the assumption of homoscedasticity is not fulfilled, and there is a heteroscedasticity problem in the Model, as shown in the below Table 18.

Endogeneity: Fifthly, the Davidson-MacKinnon test computes a test of exogeneity for a panel regression estimated via instrumental variables. As shown in the below Table 19, the p-value is 0.000 , meaning that the test clearly rejects the null hypothesis of exogenous regressors, in other words, the regressors of the Model are endogenous in the original model and the instrumenting technique is called for.

\subsection{Dynamic Panel Estimation Results}

The two-step system GMM results are illustrated in the below Table 20. The estimation results indicate that financial inclusion significantly and negatively

Table 16. VIF values for the research variables.

\begin{tabular}{cl}
\hline Independent Variables & VIF \\
\hline FII & 1.54 \\
Lending Interest Rate & 1.25 \\
Foreign Exchange Rate & 1.03 \\
Broad Money & 1.74 \\
Foreign Exchange Reserves & 1.27 \\
Mean VIF & 1.37 \\
\hline
\end{tabular}

Source: Calculated by the author on STATA 16 .

Table 17. Results for wooldridge test.

\begin{tabular}{cl}
\hline F & 7.487 \\
Probability > F & 0.009 \\
\hline
\end{tabular}

Source: Calculated by the author on STATA 16 .

Table 18. Results for likelihood ratio test.

\begin{tabular}{cc}
\hline LR chi $^{2}$ & 308.25 \\
Probability $>$ chi $^{2}$ & 0.000 \\
\hline
\end{tabular}

Source: Calculated by the author on STATA 16.

Table 19. Endogeneity test results.

\begin{tabular}{cc}
\hline Davidson-MacKinnon test of exogeneity & 128.272 \\
P-value & 0.000 \\
\hline
\end{tabular}

Source: Calculated by the author on STATA 16 . 
Table 20. System GMM results.

\begin{tabular}{|c|c|}
\hline Variables & GMM \\
\hline Lag Inflation Rate & $\begin{array}{l}0.458^{* * *} \\
(0.0284)\end{array}$ \\
\hline FII & $\begin{array}{c}-4.666^{* * *} \\
(0.884)\end{array}$ \\
\hline Interest Rate & $\begin{array}{l}0.442^{\star * *} \\
(0.0304)\end{array}$ \\
\hline Foreign Exchange Rate & $\begin{array}{c}3.61 \mathrm{e}-05 \\
(2.23 \mathrm{e}-05)\end{array}$ \\
\hline Broad Money & $\begin{array}{l}-0.00937 \\
(0.00818)\end{array}$ \\
\hline Foreign Reserves & $\begin{array}{l}0.0134^{* * *} \\
(0.00146)\end{array}$ \\
\hline Constant & $\begin{array}{l}0.535 \\
(0.404)\end{array}$ \\
\hline Observations & 333 \\
\hline Groups/Instruments & 37 \\
\hline Year Dummies & Yes \\
\hline $\mathrm{AR}(2)$ test & 0.154 \\
\hline Hansen test & 0.994 \\
\hline
\end{tabular}

Source: Calculated by the author on STATA 16. Note: Standard errors are in parentheses. Note: $* * *$ statistically significant at the $1 \%$ level.

impacts the inflation rate in developing countries. In other words, whenever financial inclusion increases by 1 unit, the inflation rate will decrease by 4.66 units. The findings are in line with Mbutor and Uba (2013); Mehrotra and Yetman (2014); Lenka and Bairwa (2016); El Sherif, (2019); Saraswati et al. (2020), who show that financial inclusion has a significant negative impact on the inflation rate. In other words, financial inclusion positively affects the effectiveness of the monetary policy, as reflected by the inflation rate. This finding is opposite to Ascari, Colciago and Rossi (2011) and Lapukeni (2015), who found out that financial inclusion does not impact the effectiveness of monetary policy significantly in Malawi. The outcome of this study also is opposite to that of Evans (2016), who found that the inflation rate has a significant impact on financial inclusion and not the other way.

As for the control variables, results reveals that the interest rate has a significant but positive impact on the inflation rate. This outcome is opposite to what was expected (negative impact). Moreover, the results indicated that the foreign reserves positively impacts the inflation rate in developing countries as expected in subsection 3.2.2. On the other hand, broad money and foreign exchange rate do not have statistical significance and do not impact the inflation rate in devel- 
oping countries.

\section{Conclusion and Policy Implications}

This paper constructed a new multidimensional FII for 37 developing economies using weights derived from PCA in aggregating indicators for access, usage, and quality following Camara and Tuesta, (2014) and Park and Mercado, (2018) using the FAS database. This index can be used to compare the extent of financial inclusion across different countries and to monitor their progress over time. This index can be of use also to researchers to assess empirically the impact of financial inclusion on other macroeconomic indicators such as poverty, economic growth, inequality, and unemployment rate. Moreover, this paper assessed the impact of financial inclusion on the inflation rate in developing countries using dynamic panel estimation. The estimates provided evidence that an increase in the level of financial inclusion leads to a decrease in the inflation rate.

Therefore, governments and central banks should put too much emphasis and increase their attention and focus on increasing the level of financial inclusion, not only financial access but also financial usage. The findings of this study could help foster a better policy to reform the financial sector, in general, by demonstrating how broadening the access and use of banking services, in particular, can have a significant direct impact on the inflation rate in developing countries. Governments should play a positive role in promoting financial inclusion by incorporating it into national development strategies. Additionally, the relevant legislative and regulatory work should be improved to support this achievement. The regulatory framework is expected to be designed to facilitate expanding account ownership, such as through licensing bank agents, reducing documentation requirements, requiring banks to provide basic or low-fee accounts, allowing the evolution of new technologies such as mobile money, and enacting dedicated legislation to regulate microcredit activities and Microfinance Institutions (MFIs).

Furthermore, as mentioned above governments should shed light on raising awareness of financial literacy as it is considered an instrument to expand and broaden financial inclusion, in other words it is a primary step for financial inclusion as it increases people's understanding and therefore makes people seek and receive financial services and products. Establishing an authority that operates as a financial literacy hub including; research, collaboration, and financial education development is recommended. Alliance with policy makers, industry players and academicians will be meaningful in strengthening and co-ordinating, information exchange. The collaboration would be able to widen alertness of financial literacy and good practice in handling financial issues. Improving the levels of nation's financial literacy directly can also be achieved with the aid of the industry players and academicians through various methods for instance round table dialogues, conferences, campaigns, and financial education fairs. Also the mass media such as television commercials, radio casting and newspaper articles can 
be used to highlight financial literacy. Moreover, banks and financial institutions representatives could offer orientation sessions and marketing activities to broaden the knowledge of financially illiterate individuals and institutions.

Finally, every country should strengthen the exchange of experiences between countries through international financial organizations, such as the AFI and the GPFI. Such organizations must work together to develop financial inclusion in developing countries with low levels of financial inclusion.

The study is limited in terms of available data. Information on financial inclusion indicators is still limited. The mobile phone used to receive money (\% of adult population); had to be left out owing to unavailability in the period under study. While several aspects of financial inclusion (availability, access, usage) are usually incorporated into these dimensions, other important dimensions are often missing, such as the data on indicators of quality of services, financial litera$c y$, and the adequacy of financial infrastructures due to the unavailability of data. Therefore the FII can be extended later once the data for these dimensions are available. Moreover, this study is limited to banking institutions; however, better results may emerge if MFIs are included, because these institutes may have healthier penetration in rural areas. Future research studies must validate these findings in light of the role of MFIs.

\section{Conflicts of Interest}

The authors declare no conflicts of interest regarding the publication of this paper.

\section{References}

Agoba, A. M., Sare, Y. A., \& Bugri-Anarfo, E. (2017). Financial Inclusion and Monetary Policy: A Review of Recent Studies. Ghana Journal of Development Studies, 14, 231-254. https://doi.org/10.4314/gjds.v14i1.12

Akanbi, S. B., Dauda, R. O., Yusuf, H. A., \& Abdulrahman, A. I. (2020). Financial Inclusion and Monetary Policy in West Africa. Journal of Emerging Economies and Islamic Research, 8, 88-99. https://doi.org/10.24191/jeeir.v8i2.8161

Amidzic, G., Massara, A., \& Mialou, A. (2014). Assessing Countries' Financial Inclusion Standing-A New Composite Index. IMF Working Papers.

Andrianaivo, M., \& Kpodar, K. (2012). Mobile Phones, Financial Inclusion, and Growth. Review of Economics and Institutions, 3, 1-30. https://doi.org/10.5202/rei.v3i2.75

Arellano, M., \& Bover, O. (1995). Another Look at the Instrumental Variable Estimation of Error-Components Models. Journal of Econometrics, 68, 29-51. https://doi.org/10.1016/0304-4076(94)01642-D

Ascari, G., Colciago, A., \& Rossi, L. (2011). Limited Asset Market Participation: Does It Really Matter for Monetary Policy? SSRN Electronic Journal.

https://doi.org/10.2139/ssrn.1948412

Bilbiie, F. O. (2008). Limited Asset Markets Participation, Monetary Policy and (Inverted) Aggregate Demand Logic. Journal of Economic Theory, 140, 162-196.

https://doi.org/10.1016/j.jet.2007.07.008

Blando, S. C. F. (2013). Linking Financial Inclusion and Development. 
Blundell, R., \& Bond, S. (1998). Initial Conditions and Moment Restrictions in Dynamic Panel Data Models. Journal of Econometrics, 87, 115-143. https://doi.org/10.1016/S0304-4076(98)00009-8

Burguillos, J.-A., \& Cassimon, D. (2020). Determinants of Inter-Regional Financial Inclusion Heterogeneities in the Philippines (No. 2020.01).

Cámara, N., \& Tuesta, D. (2014). Measuring Financial Inclusion: A Multidimensional Index. BBVA Research Working Papers. https://www.bis.org/ifc/publ/ifcb47p.pdf

Chibba, M. (2009). Financial Inclusion, Poverty Reduction, and the Millennium Development Goals. European Journal of Development Research, 21, 213-230. https://doi.org/10.1057/ejdr.2008.17

Colciago, A. (2011). Rule-of-Thumb Consumers Meet Sticky Wages. Journal of Money, Credit and Banking, 43, 325-353. https://doi.org/10.1111/j.1538-4616.2011.00376.x

Coppock, S. (2013). The Everyday Geographies of Financialization: Impacts, Subjects and Alternatives. Cambridge Journal of Regions, Economy and Society, 6, 479-500. https://doi.org/10.1093/cjres/rst012

Di Bartolomeo, G., \& Rossi, L. (2007). Effectiveness of Monetary Policy and Limited Asset Market Participation: Neoclassical versus Keynesian Effects. International Journal of Economic Theory, 3, 213-218. https://doi.org/10.1111/j.1742-7363.2007.00056.x

El Sherif, M. (2019). The Relationship between Financial Inclusion and Monetary Policy Transmission: The Case of Egypt. IISES International Academic Conference, London, May 2019, 91-115. https://doi.org/10.20472/IAC.2019.045.014

Evans, O. (2016). The Effectiveness of Monetary Policy in Africa : Modeling the Impact of Financial Inclusion. Iranian Economic Review, 20, 327-337.

Gali, J., Lopez-Salido, J. D., \& Valles, J. (2004). Rule-of-Thumb Consumers and the Design of Interest Rate Rules. Journal of Money, Credit, and Banking, 36, 739-763. https://doi.org/10.1353/mcb.2004.0064

Gardeva, A. (2010). A Vision for Full Financial Inclusion. https://www.centerforfinancialinclusion.org/a-vision-for-full-financial-inclusion

Ghosh, S. (2011). Does Financial Outreach Engender Economic Growth? Evidence from Indian States. Journal of Indian Business Research, 3, 74-99. https://doi.org/10.1108/17554191111132206

Goland, T., Bays, J., \& Chaia, A. (2010). From Millions to Billions: Achieving Full Financial Inclusion. Washington DC: Mckinsey \& Company.

Gupte, R., Venkataramani, B., \& Gupta, D. (2012). Computation of Financial Inclusion Index for India. Procedia-Social and Behavioral Sciences, 37, 133-149. https://doi.org/10.1016/j.sbspro.2012.03.281

Hannig, A., \& Jansen, S. (2010). Financial Inclusion and Financial Stability: Current Policy Issues. ADBI Working Paper. https://doi.org/10.2139/ssrn.1729122

Hartnell, N. (2019). “Uneven” Financial Access Is Hidden in the Bahamas. http://www.tribune242.com/news/2019/mar/27/uneven-financial-access-hidden-baha $\underline{\text { mas }}$

IMF (2019). Financial Access Survey 2019 Trends and Developments.

Khan, M. S. (1979). Inflation and International Reserves: A Time-Series Analysis. Staff Papers -International Monetary Fund, 26, 699-724. https://doi.org/10.2307/3866967 http://www.jstor.org/stable/3866967

Kiganda, E. O. (2014). Relationship between Inflation and Money Supply in Kenya. Journal of Social Economics, 2, 63-83. http://www.rassweb.com

Kim, D. W., Yu, J. S., \& Hassan, M. K. (2017). Financial Inclusion and Economic Growth 
in OIC Countries. Research in International Business and Finance, 43, 1-14. https://doi.org/10.1016/j.ribaf.2017.07.178

Kumar, C., \& Mishra, S. (2009). Banking Outreach and Household Level Access: Analyzing Financial Inclusion in India. 13th Annual Conference on Money and Finance in the Indian Economy, Mumbai.

Lapukeni, A. F. (2015). The Impact of Financial Inclusion on Monetary Policy Effectiveness: The Case of Malawi. International Journal of Monetary Economics and Finance, 8, 360-384. https://doi.org/10.1504/IJMEF.2015.073229

Le, T. H., Chuc, A. T., \& Taghizadeh-Hesary, F. (2019). Financial Inclusion and Its Impact on Financial Efficiency and Sustainability: Empirical Evidence from Asia. Borsa Istanbul Review, 19, 310-322. https://doi.org/10.1016/j.bir.2019.07.002

Lenka, S. K., \& Bairwa, A. (2016). Does Financial Inclusion Affect Monetary Policy in SAARC Countries? Cogent Economics and Finance, 4, Article ID: 1127011. https://doi.org/10.1080/23322039.2015.1127011

Lochy, J. (2020). Financial Inclusion-A Word with Many Meanings. https://www.finextra.com/blogposting/18441/financial-inclusion--a-word-with-manymeanings

Mbutor, O., \& Uba, I. (2013). The Impact of Financial Inclusion on Monetary Policy in Nigeria. Journal of Economics and International Finance, 5, 318-326. https://doi.org/10.5897/JEIF2013.0541

Mehrotra, A., \& Nadhanael, G. V. (2016). Financial Inclusion and Monetary Policy in Emerging Asia. In S. Gopalan, \& T. Kikuchi (Eds.), Financial Inclusion in Asia (pp. 93-127). Berlin: Springer. https://doi.org/10.1057/978-1-137-58337-6 4

Mehrotra, A., \& Yetman, J. (2014). Financial Inclusion and Optimal Monetary Policy. Bank for International Settlements Working Papers.

https://www.bis.org\%0Ahttps://poseidon01.ssrn.com/delivery.php?ID=5131031030091 2300011010608008711107409704201404802302512111407811700109711309906612402 7012010041026121034089064030123119115008017009044015049100028117077086023 09506806501308311212308808708909

Minhaj, A., Shujahat, H. H., Muhammad, R. N., \& Ahmer, B. (2019). Does Financial Inclusion Enhance Economic Growth? Empirical Evidence from the IDB Members' Countries. SSRN Electronic Journal.

Monfared, S. S., \& Akın, F. (2017). The Relationship between Exchange Rates and Inflation: the Case of Iran. European Journal of Sustainable Development, 6, 329-340. https://doi.org/10.14207/ejsd.2017.v6n4p329

Nguyen, T. T. H. (2020). Measuring Financial Inclusion: A Composite FI Index for the Developing Countries. Journal of Economics and Development. https://doi.org/10.1108/JED-03-2020-0027

Park, C.-Y., \& Mercado, R. V. (2018). Financial Inclusion: New Measurement and CrossCountry Impact Assessment. ADB Economics Working Paper Series No. 539. https://doi.org/10.22617/WPS189270-2

Roodman, D. (2006). How to Do Xtabond2: An Introduction to "Difference" and "System" GMM in STATA. Washington DC: Center for Global Development (No. 103). https://doi.org/10.2139/ssrn.982943

Saraswati, B. D., Maski, G., Kaluge, D., \& Sakti, R. K. (2020). The Effect of Financial Inclusion and Financial Technology on Effectiveness of the Indonesian Monetary Policy. Business: Theory and Practice, 21, 230-243. https://doi.org/10.3846/btp.2020.10396

Sharma, D. (2016). Nexus between Financial Inclusion and Economic Growth: Evidence 
from the Emerging Indian Economy. Journal of Financial Economic Policy, 8, 13-36. https://doi.org/10.1108/JFEP-01-2015-0004

Shirin, A. (2016). Overview of Financial Inclusion in Bangladesh. Modern Social and Cultural Studies, 63.

Suman (2017). Financial Inclusion: A Systematic Literature Review of Recent Studies. Asian Journal of Research in Banking and Finance, 7, 14-18. https://doi.org/10.5958/2249-7323.2017.00127.4

United Nations (2006). Building Inclusive Financial Sector for Development. New York.

United Nations (2020). World Economic Situation and Prospects. http://www.un.org/en/development/desa/policy/wesp/wesp archive/2013wesp.pdf

Windmeijer, F. (2005). A Finite Sample Correction for the Variance of Linear Two-Step GMM Estimators. Journal of Econometrics, 126, 25-51. https://doi.org/10.1016/j.jeconom.2004.02.005

World Bank (2015). Peru Launches National Financial Inclusion Strategy to Expand Financial Inclusion.

https://www.worldbank.org/en/news/feature/2015/08/05/peru-launches-national-finan cial-inclusion-strategy-to-expand-financial-inclusion

World Bank (2018). Financial Inclusion At-a-Glance. https://www.worldbank.org/en/topic/financialinclusion

Yorulmaz, R. (2012). Financial Inclusion and Economic Development: A Case Study of Turkey and a Cross-Country Analysis of European Union. Clemson, SC: Clemson University.

Yorulmaz, R. (2013). Construction of a Regional Financial Inclusion Index in Turkey. Journal of BRSA Banking and Financial Markets, 7, 79-101.

Yorulmaz, R. (2018). An Analysis of Constructing Global Financial Inclusion Indices. Borsa Istanbul Review, 18, 248-258. https://doi.org/10.1016/j.bir.2018.05.001 